\title{
各種建築材料の放射能含有量 \\ NATURAL RADIOACTIVITY CONCENTRATIONS IN BUILDING MATERIALS
}

\author{
伊藤和 男*，浅野賢二** \\ Kazuo ITO and Kenji ASANO
}

\begin{abstract}
As part of our study program on environmental radiation levels in buildings, we have undertaken to measure the natural radioactivity, such as radium-226, thorium-232, and potassium-40 in various inorganic building materials.

The specimens of their materials include cements, aggregates, concretes, asbestos cement slates, tiles,gypsum boards, rock wool boards, bricks, wall clays, soils, phosphorous ore,zirconia,zircon flower and zircon sand that used in Japan.

The ranges and mean values of natural radioactivity concentrations existing in their materials are tabulated and evaluated.
\end{abstract}

Kegnoords: radioactivity, building material, radium-226, thorium-232, potassium-40, radon 放射能，建材料，ラジウム -226 , トリウム -232 , カリウム -40 , ラドン

\section{1.はじめに}

原子放射線の影艟に関する国連科学委員会（UNSCEAR）の1988年の 嫂告㝜”によれば，一般環境において人が自然放射線によって被曝

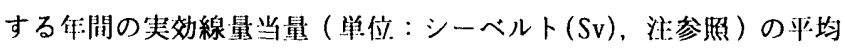
的な值は約 $2.4 \mathrm{mSv}$ であり，その約 $54 \%$ に相当する約 $1.3 \mathrm{mSv}$ がラドン ・トロンとそれらの娘核種による肺の体内被睬線鼠であるとしてい る。一方，建築構法の高度化により，従来に比へて格殷に気徱性の 高い建築物が出現し，居住環境におけるラドン・トロンとそれらの 娘核㮔の濃度が必然的に高められることとなった。このようなこと から，近年，生活環境における自然放射線（能）についても人さ.放 射線の場合と同様にその被暞によるリスクを考虑する必要が生じて きている。

放射線施設あるいは医㞠施設における人に放射線による被眿形態 と企く间梯に，生活㻴境においても放射線による被樭の形態は：つ

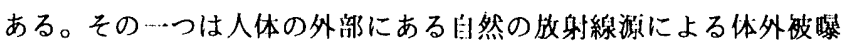
とよばれるものであり，もう…つは呼吸あるいは練四的に提取され る自然の放射性核種に起因する体内被睬とよばれるものである。

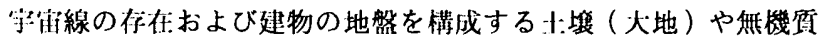
系の建築材料・部材に地球起源の白然放射吽核種が多少は含まれて いるなどの理目により，建物内では次のような戊射線被樭を受ける。

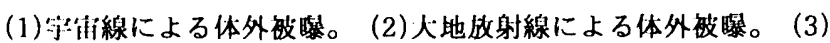
建筑材料・部材から战射されるガンマ線による体外被䁬。(1)建箱 材料・部材から敖䢠するラドン・トロンとそれらの娘核種による体 内被䀧。（5) 大地から橵选するラドン・トロンとそれらの娘核種に よる体内被眺（ラドン・トロンとそれらの娘核種による体外被睡も 多少はある）。

それ敌，建筑分野では，次のような事項が関心事となっている。

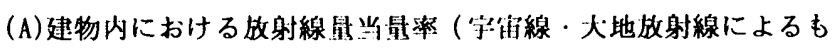
のの他に建筑材料・㰾材に起财するものを含む）に閣すること。 (B) 建物内のラドン濃度形成のメカニズムに関すること。

(C)地下街などの㸱然璪境における放射線レベル関すること。

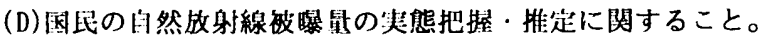

以に:の(A)〜(D)の报項を解明するためには，基盤的な資料として 本研究の!:題である「齐程处築材料の放射能含份易」の明確化が不

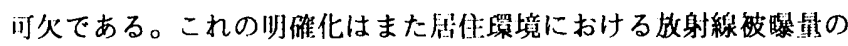
低減対策にもつながるものである。

本研究では，人が…11の大半を過こしている建物内の放射線レぺ

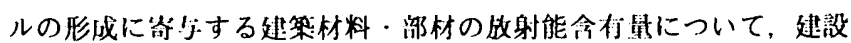

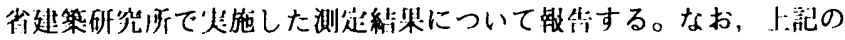
(B)の扩については文献 2)でー一部教告济みである。

\footnotetext{
本報告は文献3）１0）に加筆・修正を加えたものである。

* 建材技術研究所 技術委員.工博

(元建設省建築研究所)

** 筑波技術短期大学建筑工学科 教授 - 工焂 (元建設省建築研究所)
} 


\section{2. 天然の施射性核源について}

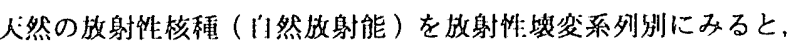
ウラン系列の場令は ${ }^{222} \mathrm{Rn}$ (ラドン 222) と ${ }^{21 \times} \mathrm{Rn}($ ラドン 218) が, トリウム系列の場令は ${ }^{220} \mathrm{Rn}$ (ラドン 220 , 別名トロン) が, アクチニウム系列の皆介は ${ }^{219} \mathrm{Rn}$ (ラトン 219 , 別名アクチノン) がそれぞれ牛成する。ラドンはアルファ線を放虫する無色・無县の 放射件希ガスである。これらのラドンの忙減期は， ${ }^{222} \mathrm{Rn}: 3.811$ ， $2^{218} \mathrm{Rn}: 3.5 \times 10^{-2}$ 秒, ${ }^{220} \mathrm{Rn}: 55.6$ 秒, ${ }^{219} \mathrm{Rn}: 3.96$ 秒である。 ${ }^{218} \mathrm{Rn}$ および ${ }^{219} \mathrm{Rn} は$ 半減期がきわめて知いので、牛成してもただ

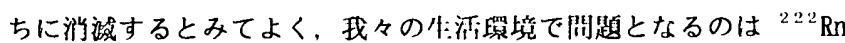

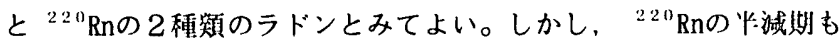
それはど长いとはいえないので，埸介によっては無視できることも

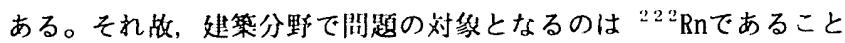
が多い。 ${ }^{222} \mathrm{Rn} は{ }^{226} \mathrm{Ra}$ (ラジウム 226 、半減期：1600华）が放射 性埋密して生成する。また, ${ }^{220} \mathrm{Rn} は{ }^{224} \mathrm{Ra}$ (ラジウム 224 、米減 期：3.66日）が放射件畩変して牛成する。

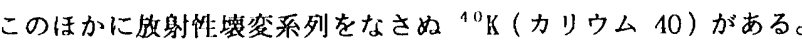

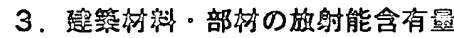

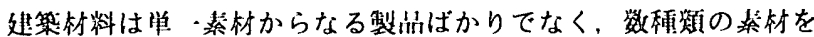
襀介した製品も数多く使用されており，思わぬ钤料がかなりの刑の

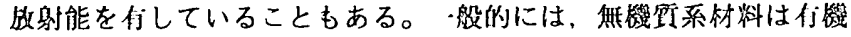

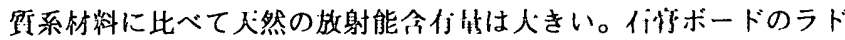

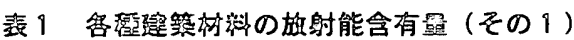

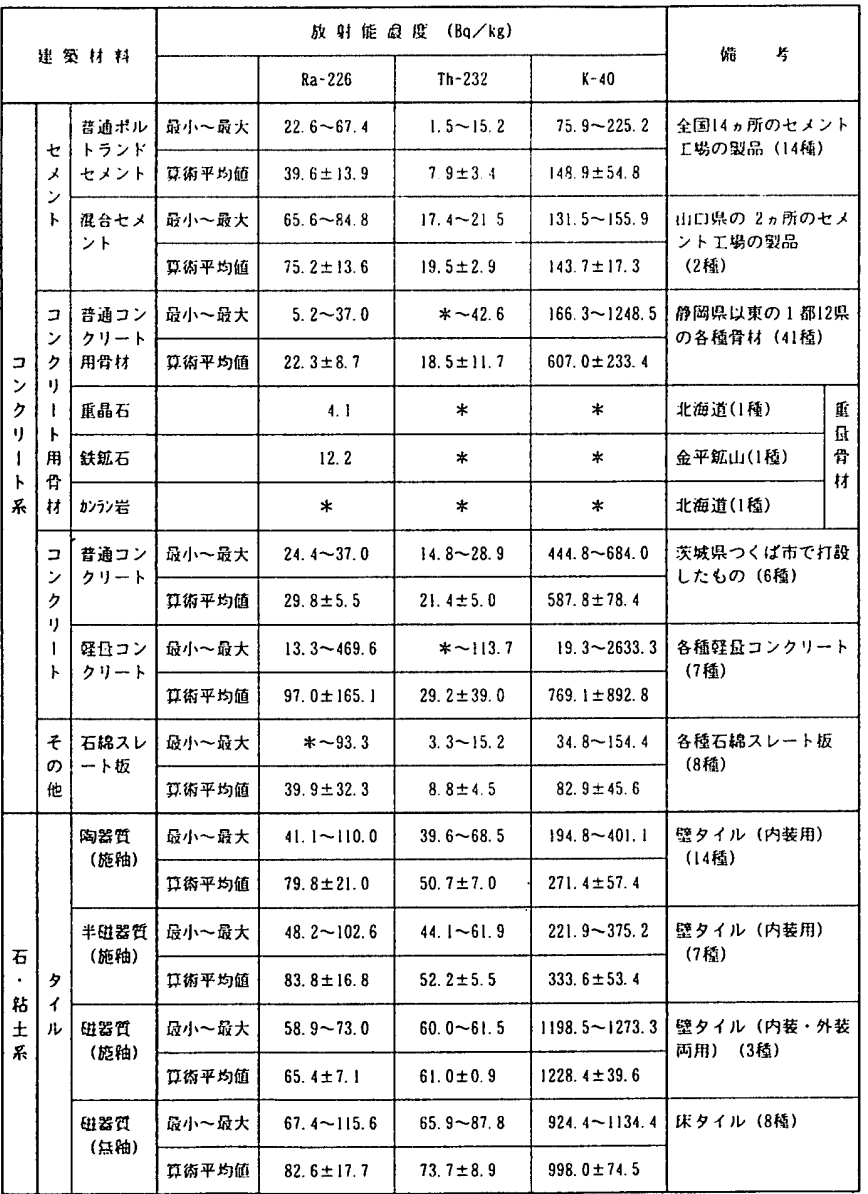

*印：ハッククラウントはト

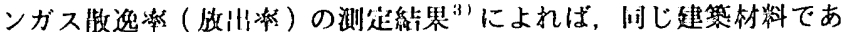

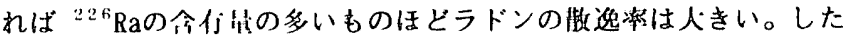

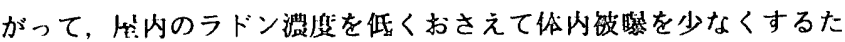

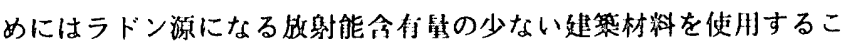

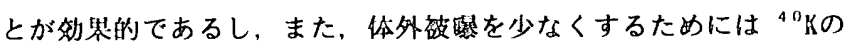

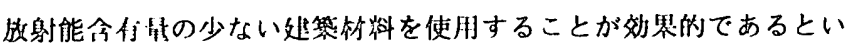

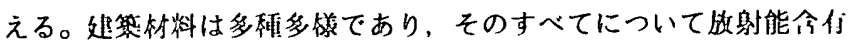

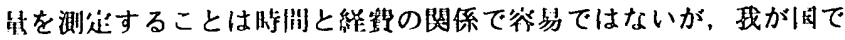

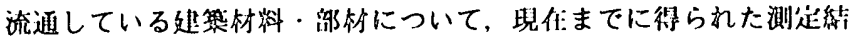

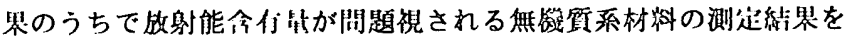

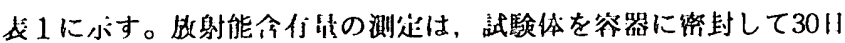

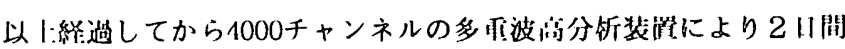

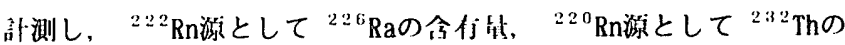

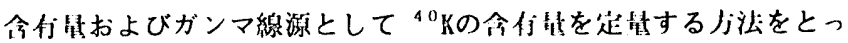

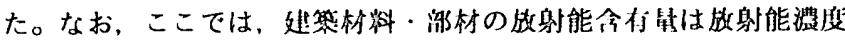
（Bq/kg）でぶす。

\section{1 コンクリート采树激・部游の放射能含有墨}

3.1 .1 セタント

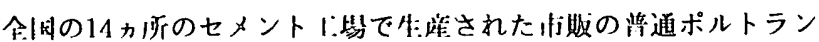

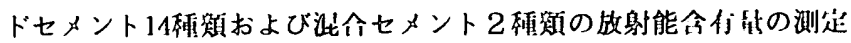
絬黙を衣1（その1）に心す。

(1) 舶通杂ルトランドセガント

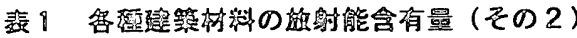

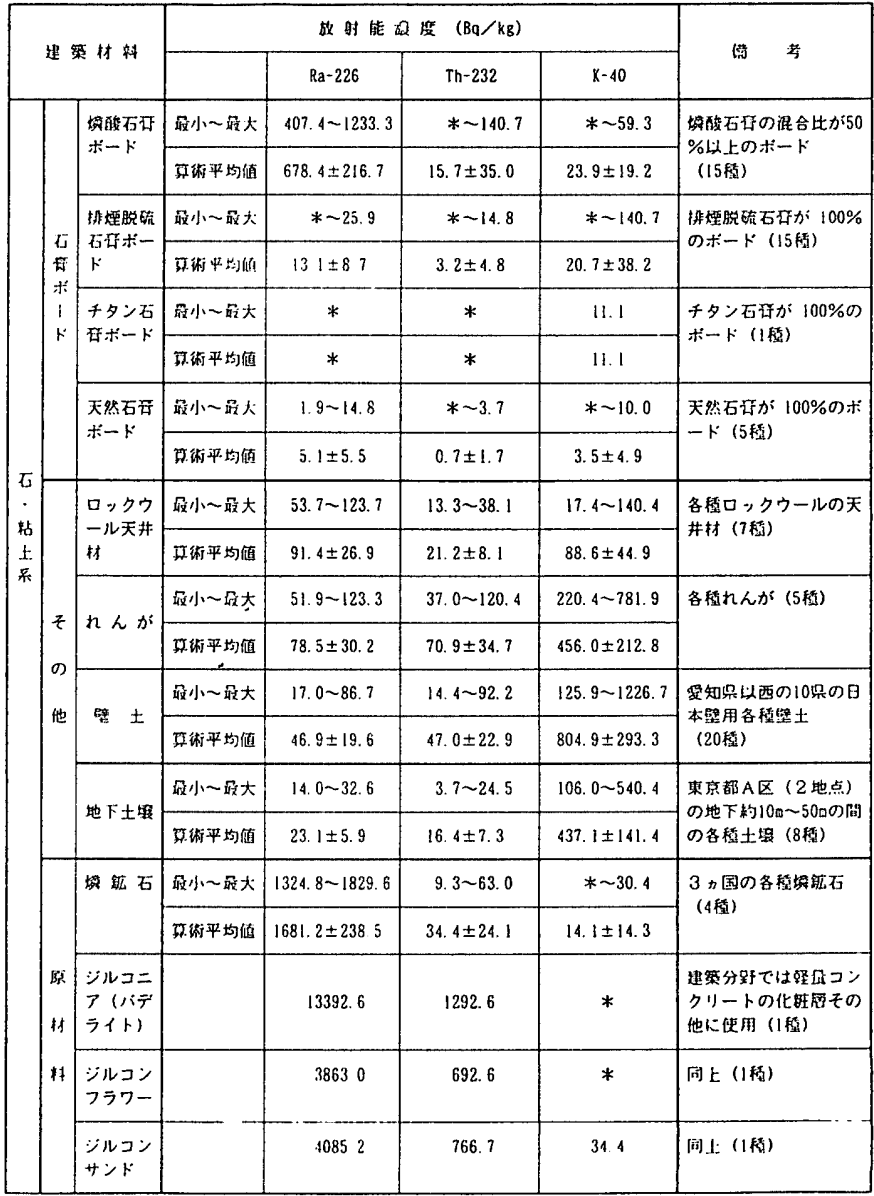

*k:1 : ハッククラウントは 
普通ポルトランドセメントの ${ }^{226} \mathrm{Ra}$ の放射能漂度は22.6〜 $67.4 \mathrm{~Bq}$

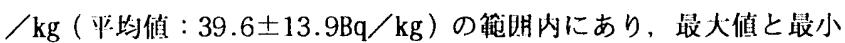
佔との差は約 3 倍ほどである。 ${ }^{232} \mathrm{Th} の$ 放射能濃度は $1.5 \sim 15.2 \mathrm{~Bq}$

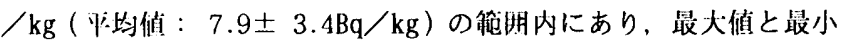

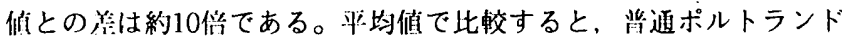
セメントの ${ }^{232} \mathrm{Th}$ は ${ }^{226} \mathrm{Ra}$ の/ /5程度の放射能濃度である。 ${ }^{10} \mathrm{~K} の$

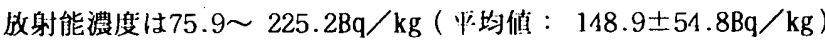
の範明内にあり，最大值と最小傎との养は約 3 倍ほどである。

(2) 混合セメント

高邚セメントやフライアッシュセメントのような诨命セメントは、 試験体数がそれぞれ 1 種類と少ないが, 前述の普通ポルトランドセ メントと此べてみると ${ }^{226} \mathrm{Ra}$ と ${ }^{232} \mathrm{Th} の$ 放射能淟度がやや高く，平

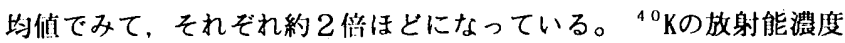
は高加セメントが $131.5 \mathrm{~Bq} / \mathrm{kg}$ ，フライアッシュセメントが 155.9 $\mathrm{Bq} / \mathrm{kg}$ であり，普通ポルトランドセメントの ${ }^{10} \mathrm{~K} の$ 放射能裣度と间 稞度である。

\section{1 .2 コンクリート用骨材}

主として関東・甲信越地方（東北地方および東游地うの一部を含

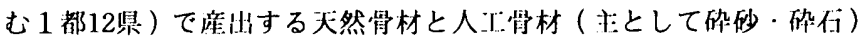
41 程類および遮蔽用コンクリートに用いる骨材として車晶不，鉄鉱 イi，カンラン岩各 1 種類の测定結果を表 1 （その1）に示す。

\section{（1）普通コンクリート用骨材}

学通コンクリート用骨材の ${ }^{226} \mathrm{Ra}$ の放射能濃度は $5.2 \sim 37.0 \mathrm{~Bq} /$ $\mathrm{kg}$ (平均值 : $22.3 \pm 8.7 \mathrm{~Bq} / \mathrm{kg}$ ) の範朋内にあり, 最大值と最小值

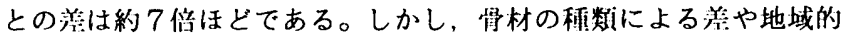
な着については，この測定結果だけでは判然としなかったもっと データ数を多くする必要があろう）。平均值で比較すると, 背通コ ンクリート用骨材の ${ }^{226} \mathrm{Ra}$ の放射能濃度は前述の背通ポルトランド セメントの平均值の約1/2である。 ${ }^{232}$ Thの放射能濃度は＊42.6 $\mathrm{Bq} / \mathrm{kg}$ (*印はバックグラウンド以下であることを亦す。以下同様。

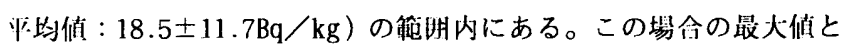
最小值の差は大きいが，骨材の種類による差や地域的な差について

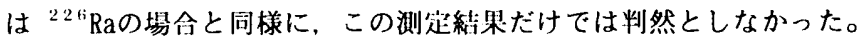
平均值で比較すると，普通コンクリート用解材の ${ }^{232} \mathrm{Th}$ の放射能濃 度は普通ポルトランドセメントの約 2 倍ほどである。 ${ }^{10} \mathrm{~K} の$ 放射能

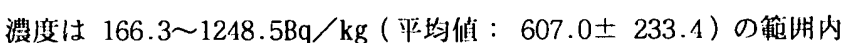
にあり，最大值と最小值との差は約8倍ほどある。標淮偏差は大き いが，あえて平均值で比較してみると ${ }^{40} \mathrm{~K} の$ 放射能浱度は曗通ポル トランドセメントの約 4 倍に相当する。

今後, 関東地方以西のコンクリート用骨材についても闹様の测起 をする必要がある。

（2）重晶石・鉄鉱石（磁鉄鉱）・カンラン岩

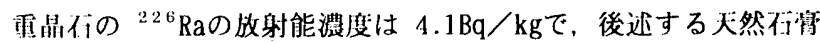

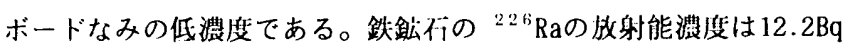

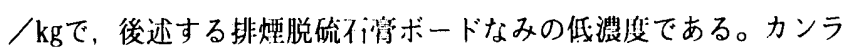
ン椞の ${ }^{226} \mathrm{Ra}$ の放射能濃度はバックグラウンド以トである。 ${ }^{232} \mathrm{Th}$ および ${ }^{40} K の$ 放射能濃度については，重晶不，鉄鉣不，カンラン临 ともにバックグラウンド以下である。これらを骨材とする透䑤月コ ンクリートの放射能含有鼠は使用するセメントの放射能含有異に低 位するといえる。

\section{1 .3 コンクリート}

茨城県筑波刷大想町（現つくば沛）で打没した 6 種類の丵通コン

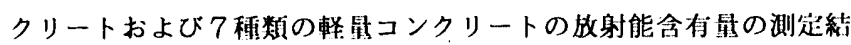
果を表1（その1）に示す。

(1) 普通コンクリート

觜通コンクリートの ${ }^{226} \mathrm{Ra},{ }^{232} \mathrm{Th}$ よび ${ }^{40} \mathrm{~K}$ 放射能濃度の斗均 值は，それぞれ29.8土5.5Bq $/ \mathrm{kg}, 21.4 \pm 5.0 \mathrm{~Bq} / \mathrm{kg}, 587.8 \pm 78.4$ $\mathrm{Bq} / \mathrm{kg}$ であり，バラッキは比較的少ない。これらの值は標辢偏差を 考虑すれば显通コンクリート用骨材の放射能濃度とほほ同等である。 コンクリートの放射能会材虬は，コンクリートの原料であるセメン トや骨材の放射能含们學およびそれらの混合此に依存するとみられ る。なお，セメントと骨材を泟練りするための通常の水の放射能含

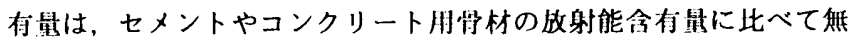
視できるほどのものであろう。

(2) 軽量コンクリート

䡫毁コンクリートの ${ }^{22 \mathrm{~h}} \mathrm{Ra}$ の放射能濃度は $13.3 \sim 469.6 \mathrm{~Bq} / \mathrm{kg}$

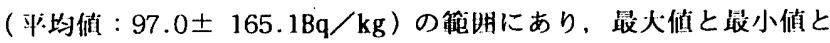
の差は約35仿である。また，ある種の軽舅コンクリートの ${ }^{226} \mathrm{Ra} の$ 放射能濃度の最大做は站还の显通コンクリートのそれの約13借ほと 高い。標染偏在が大きすぎが，あえて平均值で比較してみると， 軽量コンクリートの ${ }^{226} \mathrm{Ra}$ 放射能濃度は普通コンクリートに比へ て約3倍ほど高い。これは，後述するジルコン系材料がプレハブ住 宅川の䡫故コンクリート版（試験体）に原料の一部として使用され ていることによるものである。 ${ }^{232} \mathrm{Th} の$ 放射能濃度は*〜 $113.7 \mathrm{~Bq}$ $/ \mathrm{kg}$ (平妇值 : $29.2 \pm 39.0 \mathrm{~Bq} / \mathrm{kg}$ ) の範䎴にあり, 最大做と最小做 との着は大きい。 ${ }^{232} \mathrm{Th} の$ 放射能濃度についても ${ }^{226} \mathrm{Ra}$ の皆合と闹 様にジルコン系材料の潉人の影需がみられ, 显通コンクリートの最 大傎の 4 偪近い放射能濃度を示すものもある。 ${ }^{4} \mathrm{~K}$ Kの放射能濃度は $19.3 \sim 2633.3 \mathrm{~Bq} / \mathrm{kg}$ （平均傎： $769.1 \pm 892.8 \mathrm{~Bq} / \mathrm{kg}$ ）の公範传に わたり，最大做と最小佔との差は約 136倍ほどもある。 ${ }^{40} \mathrm{~K} の$ 皆令 も標準偏着が大きいが，あえて平均值で此較してみると，当通コン クリートの約 1.3 储ほどでしかないこれらのことは，後述するジ ルコン系材料の ${ }^{40} \mathrm{~K}$ の放射能濃度が極めて低いこととあわせて考え ると，軽㥂コンクリートに使用されている能材に山米するものと思 われる。

\section{1 .4 その他}

8 種類の不綿スレート板の放射能含标量の测定結果を表 1 （その 1) にふす。

(1) 石綿スレート板

不綿スレート板の ${ }^{226} \mathrm{Ra}$ と ${ }^{232} \mathrm{Th}$ の战射能濃度は，平均值でみて，

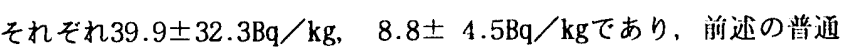
ポルトランドセメントのそれに近い值を示している。また、 ${ }^{40} \mathrm{~K} の$

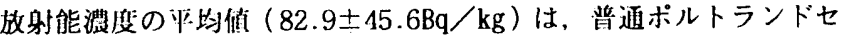
メントの最小倾に近い做をホししている䟣1には明示してないが, 别途に行った们線の放射能会住舅の測定結果 ${ }^{81}$ によると、 ${ }^{226} \mathrm{Ra}$ ， ${ }^{232} \mathrm{Th}$ および40 K の放射能濃度はいずれもバックグラウンド以トな いしはバックグラウンドを多少に:间る壁度であった。これらのこと から，们綿スレート枚の放射能含有量は，製造時に使用するセメン トの放射能会们墔に低佸するといえる。

3.2 石・粘土系材料・部材の放射能含有量 


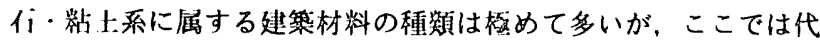
戈的ないくつかの測定結果について述へる。

\section{2 .1 タイル}

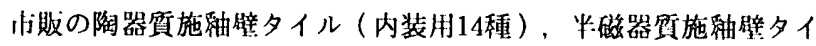

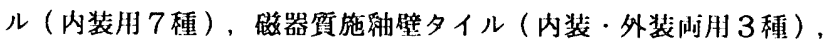

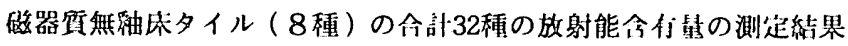
を表1(その1)に示す。

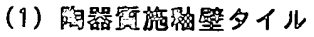

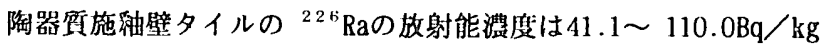
（平均值：79.8 $21.0 \mathrm{~Bq} / \mathrm{kg}$ ）の範明にあり, 最大值と最小值との 差は約3 倍ほどである。 ${ }^{232} \mathrm{Th} の$ 放射能濃度は $39.6 \sim 68.5 \mathrm{~Bq} / \mathrm{kg}$

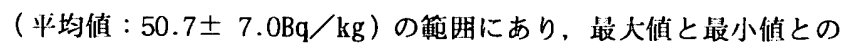
差は約 2 倍ほどである。 ${ }^{40} \mathrm{~K} の$ 放射能浱度は $194.8 〜 401.1 \mathrm{~Bq} / \mathrm{kg}$ （半均值： $271.4 \pm 57.4 \mathrm{~Bq} / \mathrm{kg}$ ) の範明にあり，最大值と最小值と の差は約 2 倍ほどである。

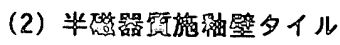

半磁器貢施䣓壁タイルの ${ }^{226} \mathrm{Ra}$ 放射能濃度は48.2〜 $102.6 \mathrm{~Bq} /$ $\mathrm{kg}$ (平均值 : $83.8 \pm 16.8 \mathrm{~Bq} / \mathrm{kg}$ ) の範明にあり, 最人做と最小值と の差は約 2 倍ほどである。半磁器質施婇壁タイルと前述の陶器質施

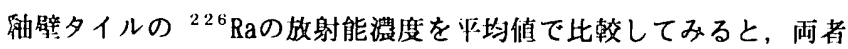
はほほ同等である。 ${ }^{232} \mathrm{Th}$ 放射能澧度は44.1〜 61.9Bq/ kg（平均 值: $52.2 \pm 5.5 \mathrm{~Bq} / \mathrm{kg}$ ）の範眀にあり, 最大佔と最小佔との差は比

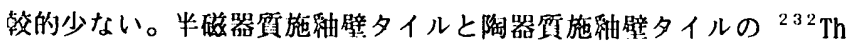
の放射能湿度を平均值で比皎してみると、峏者はほほ问等である。

${ }^{40} \mathrm{~K} の$ 放射能濃度は $221.9 \sim 375.2 \mathrm{~Bq} / \mathrm{kg}$ (斗均值 : $333.6 \pm 53.4$

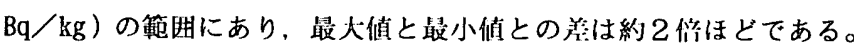

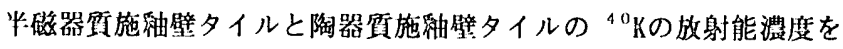

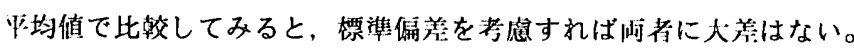

半磁器質タイルは素材区分上は陶器啠夕イルに属するためか, 今 [四の測定結果によれば，半磁器宁タイルの ${ }^{226} \mathrm{Ra},{ }^{232} \mathrm{Th},{ }^{40} \mathrm{~K} の$ 放射能濃度は陶器質タイルのそれに楻めて近い值をふした。

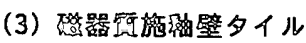

磁器蜇施袖壁タイルの ${ }^{226} \mathrm{Raおよび}{ }^{232} \mathrm{Th}$ 放射能濃度は，それ ぞれ58.9〜 73.0Bq/ kg (平均值 : $65.4 \pm 7.1 \mathrm{~Bq} / \mathrm{kg}$ )，60.0〜61.5 $\mathrm{Bq} / \mathrm{kg}$ (平均值 : $61.0 \pm 0.9 \mathrm{~Bq} / \mathrm{kg}$ ) の範曲にあり, 試験体钽が少 ないためか最大值と最小值との間に大きな差はない。磁器颃施嬏辟

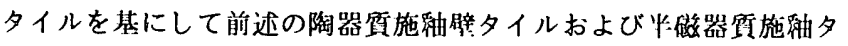

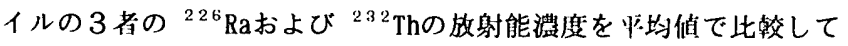

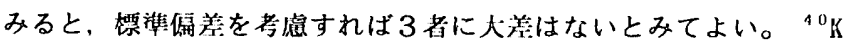

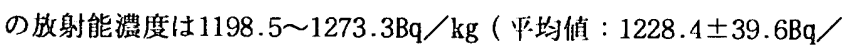
$\mathrm{kg}$ ）の範用にあり，最大值と最小值との差はほとんどないとみてよ

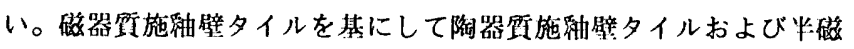

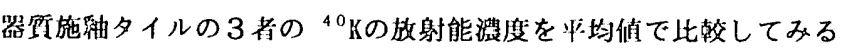

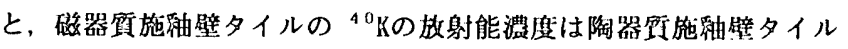

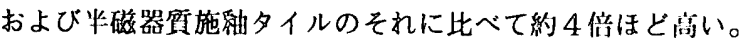

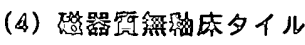

磁器筫無婇休タイルの ${ }^{226} \mathrm{Ra} の$ 放射能濃度は67.4〜 $115.6 \mathrm{~Bq} / \mathrm{kg}$

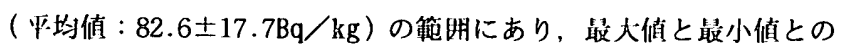
差は約 2 倍はどである。磁器筫無䣋床タイルと前述の半磁器貢施融

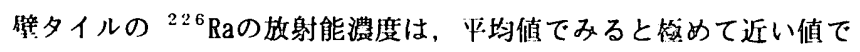

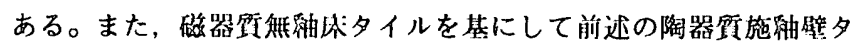

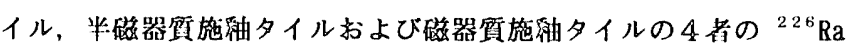

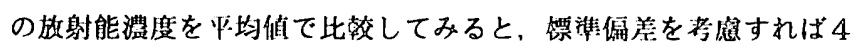
者に大差はないとみてよいであろう。 ${ }^{232} \mathrm{Th}$ の放射能漶庭は65.9 $87.8 \mathrm{~Bq} / \mathrm{kg}$ (平均值 : 73.7士 $8.9 \mathrm{~Bq} / \mathrm{kg}$ ) の範闸にあり, 最大值と

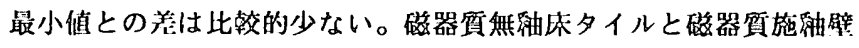

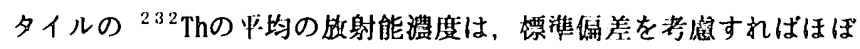

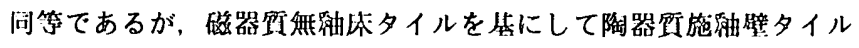

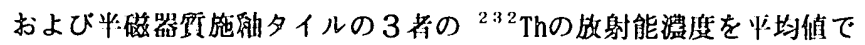

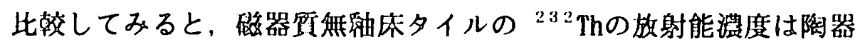

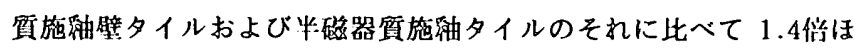
ど高い。 ${ }^{40}$ Kの放射能皘度は924.4 1134.4Bq/ $\mathrm{kg}$ (平均值 : 998.0 $\pm 74.5 \mathrm{~Bq} / \mathrm{kg}$ ）の範明にあり, 最大值と最小值に大差はない。磁器

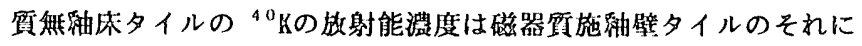

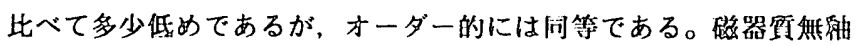

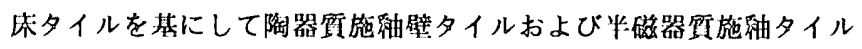

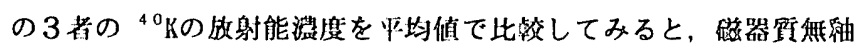

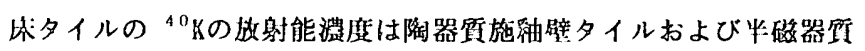
施婇タイルのそれに此へて約 3 倍ほど高い。

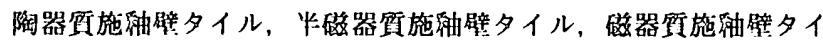

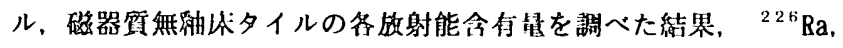

${ }^{232}$ Thの放射能湱度については 4 者間に大差はないが、 ${ }^{40} \mathrm{~K} の$ 放射

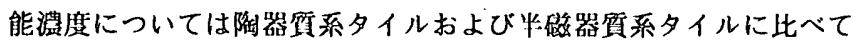
磁器颃系タイルが3〜4倍ほと高い做をぶしているのが特徵的であ る。

3.2 .2 石管ボート

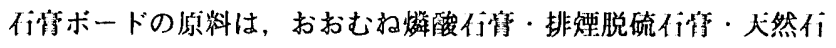

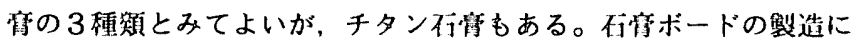
際しては，それぞれの们原耀を単独で使用する場合と適当に混合 して使用する埸合とがある。

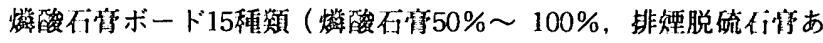
るいは天然们打50\%〜 0\%の混合比で製造されたボード)，排㖶脱

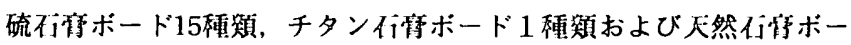

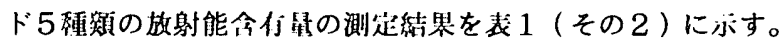

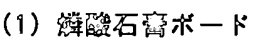

燐酸不停ボードの ${ }^{226} \mathrm{Ra}$ の放射能濃度は 407.4〜 1233.3Bq/kg

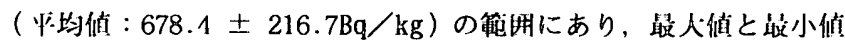

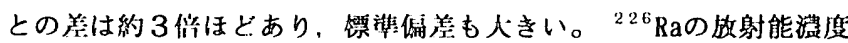

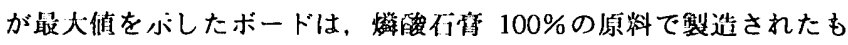

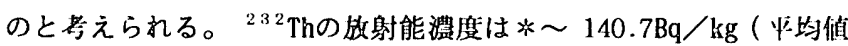

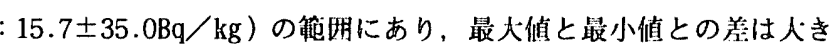

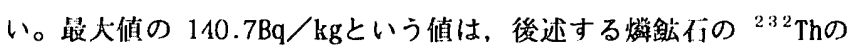
最大值の約 2 储に相当している。このことは, 試駼体として使用し

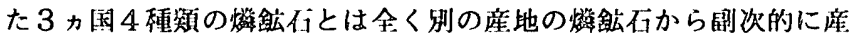

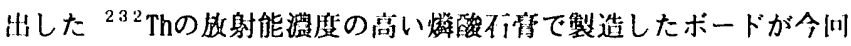

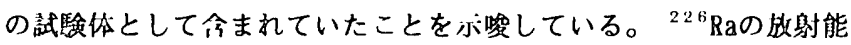

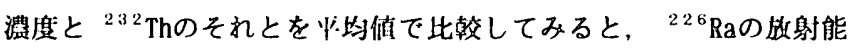

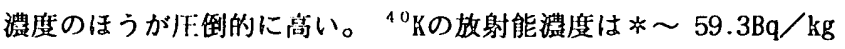

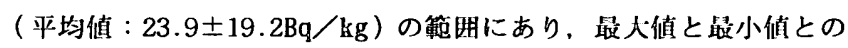

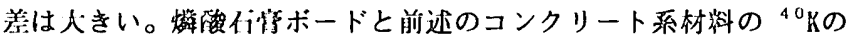


放射能濃度を平均值で此較してみると，燐酸不高ボードのそれは析 莩いに少ない。

\section{（2）排煙脱硫石高ボート}

排煙脱硫石帝ボードの ${ }^{226} \mathrm{Ra}$ の放射能濃度は*〜25.9Bq $/ \mathrm{kg}$ (平 均值 : $13.1 \pm 8.7 \mathrm{~Bq} / \mathrm{kg}$ ）の範曲にある。排洷脱硫住管ボードと前 述の燐酸石亮ボードの ${ }^{226} \mathrm{Ra} の$ 放射能濃度を平均值で比較してみる と，排煙脱硫石高ボードのそれは桁違いに少ない。 ${ }^{23}{ }^{2} \mathrm{Th}$ 放射能 濃度は*〜14.8Bq $/ \mathrm{kg}$ （平均值： $3.2 \pm 4.8 \mathrm{~Bq} / \mathrm{kg}$ ）の範㤹にあり 平均值でみて，その量は少ない。 ${ }^{40} \mathrm{~K}$ 放射能濃度は*〜110.7 Bq $/ \mathrm{kg}$ （平均值 : $20.7 \pm 38.2 \mathrm{~Bq} / \mathrm{kg}$ ）の範囲にあり，最大值と最小值 との差は大きい。平均值でみてみると，排煙脱硫石等ボードと前述 の燐酸们杽ボードの ${ }^{40} \mathrm{~K} の$ 放射能濃度は近似している。

(3) チタン石亳ボート

チタン不筲ボードの試験体数は 1 種類と少ないが，測定絬果によ れば ${ }^{226} \mathrm{Ra}$ と ${ }^{232} \mathrm{Th}$ の放射能濃度はいずれもバックグラウンド以下 である。 ${ }^{40} \mathrm{~K} の$ 放射能濃度は $11.1 \mathrm{~Bq} / \mathrm{kg}$ であり，小さな估をボして いる。

\section{（4）天然石亳ボート}

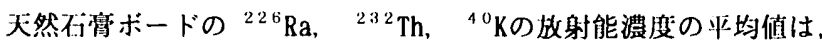
それぞれ $5.1 \pm 5.5 \mathrm{~Bq} / \mathrm{kg}, \quad 0.7 \pm 1.7 \mathrm{~Bq} / \mathrm{kg}, \quad 3.5 \pm 4.9 \mathrm{~Bq} / \mathrm{kg}$ であり，いずれも極めて小さな值を示している。

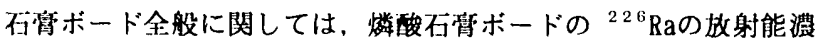
度が際立って高く，原料である燐鈖石の影繁が大きいことをうかが わせる。

\subsection{3 その他}

ロックウール天井材 7 種類，れんが 5 種類，妥知県以计の臂十20 種類，東京都内 2 地点の地下土塆 8 種類の各放射能含有量の測定結 果を表1（その2）に示す。

(1) ロックウール天井材

ロックウール天井材の ${ }^{226} \mathrm{Ra} の$ 放射能濃度は $53.7 \sim 123.7 \mathrm{~Bq} / \mathrm{kg}$ (平均值 : $91.4 \pm 26.9 \mathrm{~Bq} / \mathrm{kg}$ ) の範眀にあり，最大值と最小做との

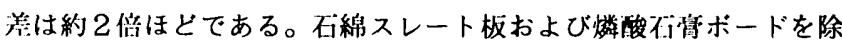
けば，板状の建築材料としてのロックウール天井材は各種不管ボー ドなどに比べて ${ }^{226} \mathrm{Ra}$ の放射能濃度は比較的漓濃度である。 ${ }^{232} \mathrm{Th}$

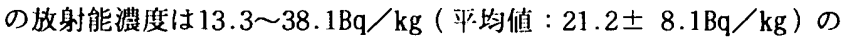
範明にあり，最大值と最小值との差は約 3 椱ほどである。平均值で みると、 ${ }^{232} \mathrm{Th}$ 放射能濃度は前述の普通コンクリートなみである。 ロックウール天井材の测定值の標淮偏关はかなり人きいが， ${ }^{232} \mathrm{Th}$

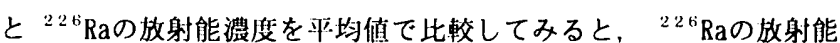
湱度のほうが約 4 倍ほと高い。 ${ }^{40} \mathrm{~K}$ の放射能濃度は $17.4 \sim 140.4 \mathrm{~Bq}$

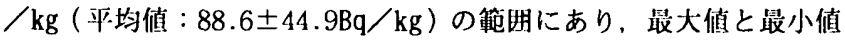
との差は約8倍ほどである。平均值で比較してみると、ロックウー ル天井材の ${ }^{40} \mathrm{~K} の$ 放射能濃度は前述の不綿スレート板なみである。

(2) れんが

5種類のれんが（普通れんがと酎火れんが）の放射能含有舅の测 定結果を表 1 （その2）に示す。れんがの ${ }^{226} \mathrm{Ra}$ 放射能濃度は51.9

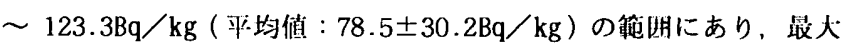
值と最小值との差は約 2 倍ほどである。 ${ }^{232} \mathrm{Th}$ の敌射能港度は 37.0 $\sim 120.4 \mathrm{~Bq} / \mathrm{kg}$ （平均值： $70.9 \pm 34.7 \mathrm{~Bq} / \mathrm{kg}$ ）の範明にあり, 最大 傎と最小值との差は約 3 倍ほどである。れんがの测定值の標染偏差

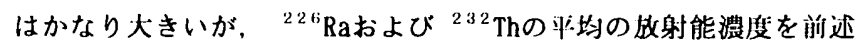
の普通コンクリートのそれと比べてみると，それぞれが約 3 倍ほど 高い。 ${ }^{40} \mathrm{~K} の$ 放射能謴度は $220.4 \sim 781.9 \mathrm{~Bq} / \mathrm{kg}$ (平均值： 456.0

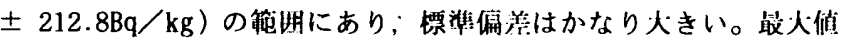
と最小值との無は約 4 倍ほどである。

(3) 壁土

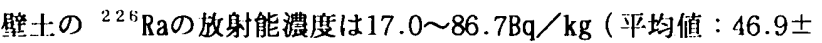
$19.6 \mathrm{~Bq} / \mathrm{kg}$ ）の範明にあり，最大做と最小值の差は約 5 佁ほどであ る。 ${ }^{232} \mathrm{Th}$ の放射能濃度は14.4 92.2Bq/kg（平均值： $47.0 \pm 22.9$ $\mathrm{Bq} / \mathrm{kg}$ ）の範粗にあり，最大值と最小做との差は約 6 倍ほとである。 ${ }^{226} \mathrm{Ra}$ と ${ }^{232} \mathrm{Th}$ の放射能濃度は同程度とみてよい。 ${ }^{40} \mathrm{~K}$ の放射能濃

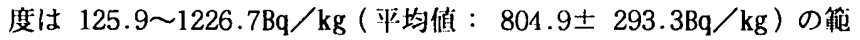
明にあり，最大值と最小做との差は約10倍ほどである。

平均值でみた場合，爱知県以西の壁士:の ${ }^{226} \mathrm{Ra},{ }^{232} \mathrm{Th},{ }^{40} \mathrm{~K} の$ 放射能濃度は、表 1 には示してないが别途に衍った茨城県つくば市 の通常の土墰の放射能濃度 $\left({ }^{226} \mathrm{Ra}: 26.2 \pm 0.8 \mathrm{~Bq} / \mathrm{kg}, \quad{ }^{232} \mathrm{Th}\right.$ : $\left.15.2 \pm 3.1 \mathrm{~Bq} / \mathrm{kg},{ }^{40} \mathrm{~K}: 212.6 \pm 12.6 \mathrm{~Bq} / \mathrm{kg}\right)^{101}$ に此して商く. それぞれ約 2 倍，約 3 倍，約 4 倍ほとである。

今後，関來地方をも含めた企国的な壁士の放射能含伤量の测足を 行い，その史態を把撜する必要があ万う。

\section{(4) 地下土慒}

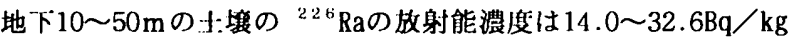
（平均值：23.1士 $5.9 \mathrm{~Bq} / \mathrm{kg}$ ）の範胁にあり，最大值と最小值との 差は約2倍ほとである。 ${ }^{232} \mathrm{Th} の$ 放射能濃度は $3.7 \sim 24.5 \mathrm{~Bq} / \mathrm{kg}$

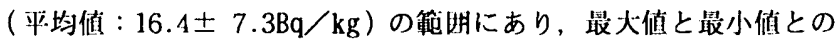
差は約 7 倍ほどである。 ${ }^{40} \mathrm{~K}$ 放射能濃度は $106.0 \sim 540.4 \mathrm{~Bq} / \mathrm{kg}$ （平均值： $437.1 \pm 141.4 \mathrm{~Bq} / \mathrm{kg}$ ）の範非にあり, 最大值と最小做 との差は約 5 倍ほどである。

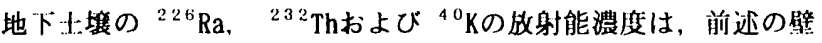
土のそれに比して、いずれも1/2程度である。

\section{2 .4 原村料}

燐鈗石 4 種類, ジルコニア 1 種類, ジルコンフラワー 1 種類, ジ ルコンサンド 1 種類の各放射能含有贸の测定結果を表 1 (その 2 ) に亦す。燐鈆不が植接的に建築材料として使用されることはないと 思われるが，燐鈗们は燐酸石等ボードの原材料であるため，その放 射能含有㔠が注目される。ジルコン系材料の用途は，すぐれた諸特 性のゆえに多う泊にわたるが，建築材料としての利用は今のところ 必ずしも多いとはいえない。1例としては解述のように軽裝コンク リートの化楖屑への適朋例があげられる。

\section{(1) 橉鉱石}

燐鉣不の ${ }^{226} \mathrm{Ra}$ 放射能濃度は $1324.8 \sim 1829.6 \mathrm{~Bq} / \mathrm{kg}$ (平均值： $1681.2 \pm 238.5 \mathrm{~Bq} / \mathrm{kg}$ ）の範囲にあり，虂めて高濃度である。最大 值と最小佰との差は $500 \mathrm{~Bq} / \mathrm{kg}$ ほどあり，産出地による相遥のある ことがうかがえる。したがって，前述の燐酸不㢼ボードの放射能含 有量は，原材料である燐鉙石の種類によって大きく左不される。 ${ }^{232} \mathrm{Th}$ の放射能濃度は 9.3 63.0Bq/ $\mathrm{kg}$ (平均值 : $34.4 \pm 24.1 \mathrm{~Bq} /$ $\mathrm{kg}$ ）の範眀にあり，それほと高濃度ではない。最大值と最小值との 差は約 7 倍ほとである。 ${ }^{40} \mathrm{~K} の$ 放射能濃度は*〜30.4Bq $/ \mathrm{kg}$ (平均

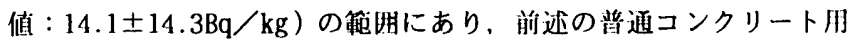
骨材のそれに此べると析避いに低い。 
(2) シルコニア

ジルコニア (バデライト) の ${ }^{226} \mathrm{Ra}$ の牧射能濃庭は13392.6 Bq/

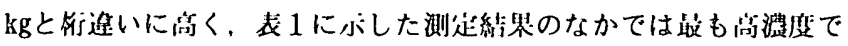

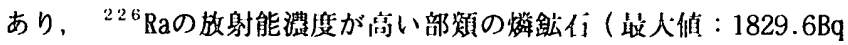

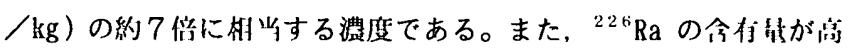

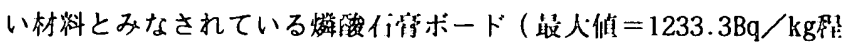

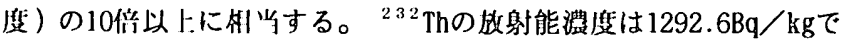

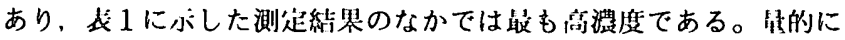

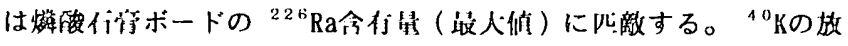
的能濃度はバックグラウンド以ドである。

(3) シルコンフラワー

ジコンフラワーの ${ }^{22 \mathrm{t}} \mathrm{Ra}$ の放射能湦度は $3863.0 \mathrm{~Bq} / \mathrm{kg}$ である。 この值は朔述のジルコニアのそれの約1/4ほどではあるが，他の建

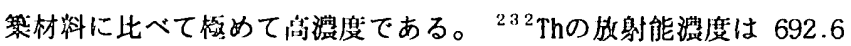
$\mathrm{Bq} / \mathrm{kg}$ で：ジルコニアのそれの約1/2ほどであるが, やはり他の建

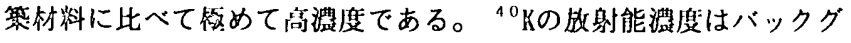
ラウンド以ドである。

(4) シルコンサンド

ジルコンサンドの ${ }^{22 \mathrm{R}} \mathrm{Ra}$ 放射能濃度は1085.2Bq/ $\mathrm{kg}$ である。こ

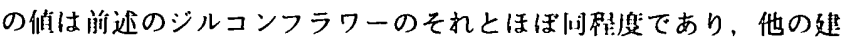

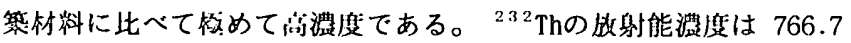
$\mathrm{Bq} / \mathrm{kg}$ であ。この值はジルコンフラワーのそれとオーダー似に们

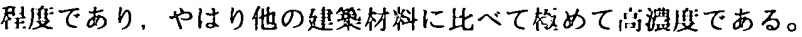

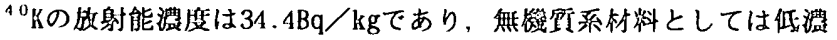
度の蔀䝷にはいる。

\section{Q. ふららりに}

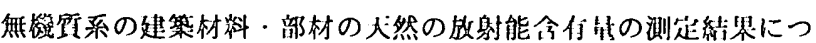
いて遮へた。各因におけるこの锺の测定例は文献1），11），12）に

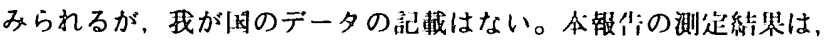

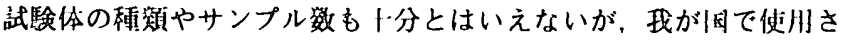

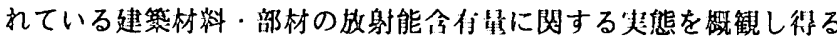
唯・のまとまったデータといえる。これにより，建物内における同

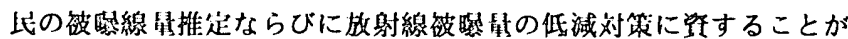

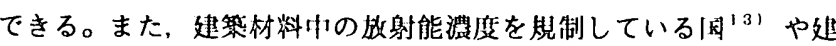

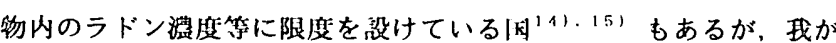

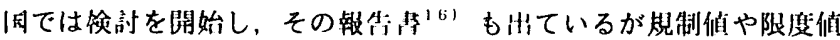
を没迁するまでには台っていない。これらのことについては，周際

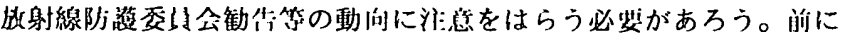

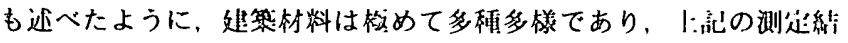

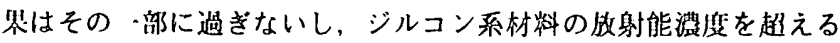
ような材阽子使用されているかもしれない。また，今後において，

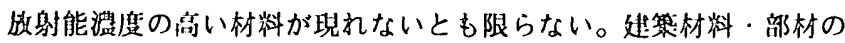

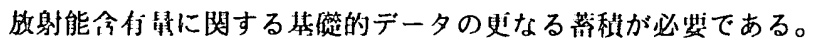

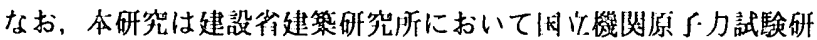
究該により起施したものである。

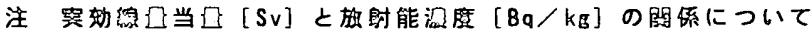

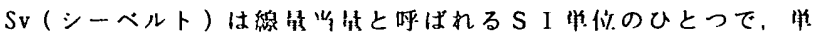

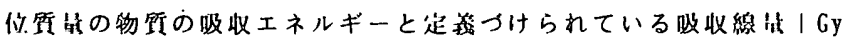

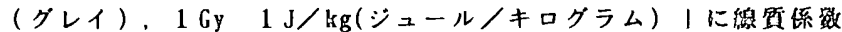

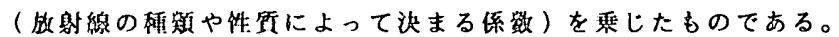
人体が故射線を受けた场介、その影节の見れかたは細微によって異

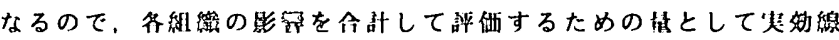
动凶周「Sv|と呼ば机るものが使われる。

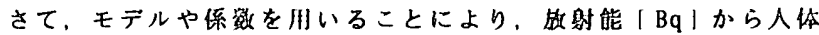
が受ける放璟能话|SV|を疗めることができる。たとえば、ラドン

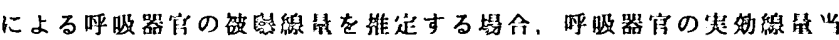
诲H｜Sv|は基本的には次式で求まる。

$$
\mathrm{H} x \cdot \mathrm{F} \cdot \mathrm{T} \cdot \mathrm{D}
$$

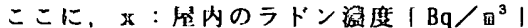

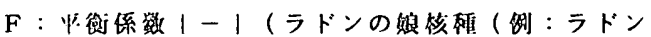

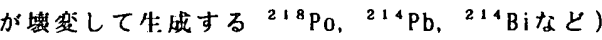
とラドンの保在比）

$\mathrm{T}: \int_{1}^{\prime}$ 位:時蔺 |h|

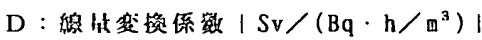

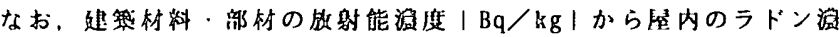

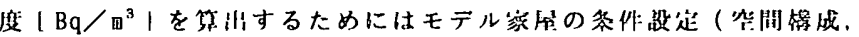

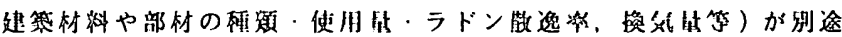
に必要となる。

得立献

1) United Nations Scientific Congittee on the Effect of Atomic Radiation : Rxposures from Natural Sources of Radiation (1988)

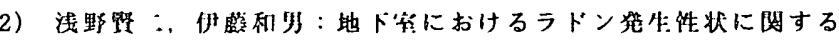

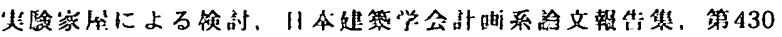
当, pp. 33〜 43 (1991.12)

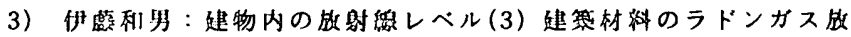

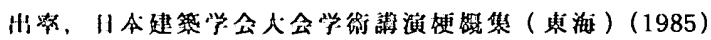

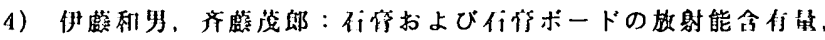

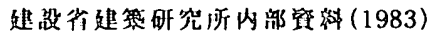

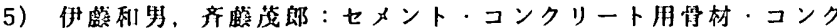

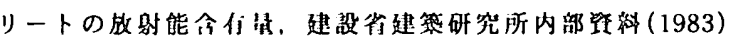

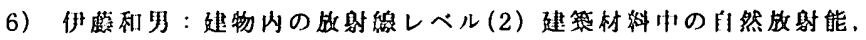

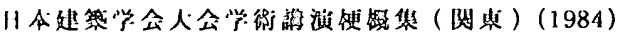

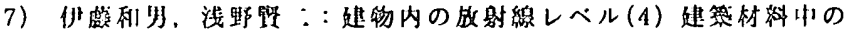

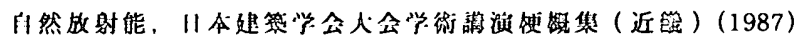

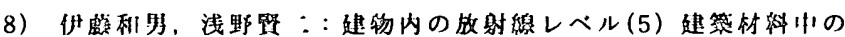

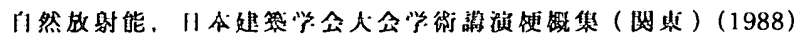

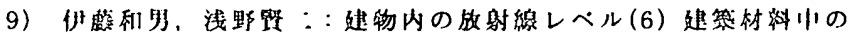

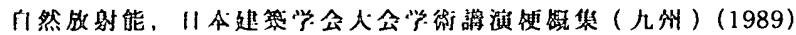

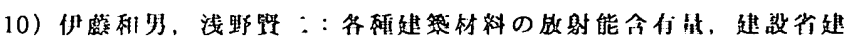

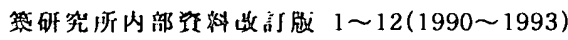

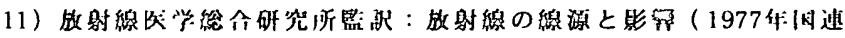

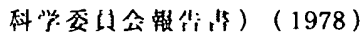

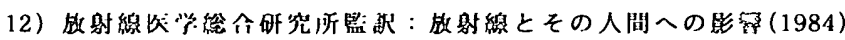

13) R.K. Collings : Uranium-Radium in Phosphate Fertilizer and Co-Product Phosphogypsum. Mineral Sciences Laboratories Report MRP 77-06, May (1977)

14) Gun Astri Svedjemark : Spedish limitation Schemes to Decrease Rn Daughters in Indoor Air. Health Physics Vol.51, No.5 (1986)

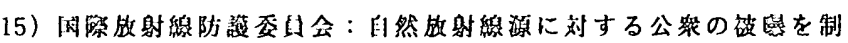

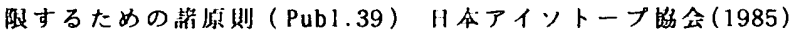

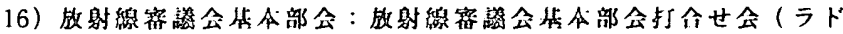

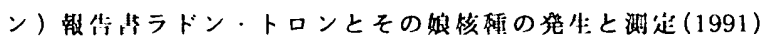

(1997年 5 月 9 日原稿受理, 1997年 9 月 8 日採用決定） 